\title{
Undergraduate Students Attitudes toward Biotechnology Crop
}

\author{
Evita Soliha Hani ${ }^{1 *}$ and Mustapit ${ }^{2}$ \\ ${ }^{1}$ Agribusiness Study Program, Faculty of Agriculture, University of Jember, Indonesia \\ ${ }^{2}$ Agricultural Extension Study Program, Faculty of Agriculture, University of Jember, Indonesia
}

\begin{abstract}
Crop biotechnology is not yet entirely accepted by all of the countries, even though biotechnology can give a lot of benefits in production. This research aims to explain undergraduate students attitudes toward crop biotechnology and to analyse factors affecting their attitudes toward crop biotechnology. This research is carried out at the University of Jember campus with a disproportionate random sampling of 80 respondents consisting of 40 students from the Faculty of Agriculture and 40 students from other faculties. The data analysis technique is logistic regression. The result of this research showed that most of the undergraduate students $(61,25 \%)$ are agree toward biotechnology crops. While factors that affected their attitudes toward biotechnology crops are information, sex, and knowledge.
\end{abstract}

\section{BACKGROUND}

Indonesia is still a rice exporting country. For five years (2012-2017), the data from [1] showed that Indonesia had imported rice (Figure 1). Based on Figure 1, the two largest rice exporter countries in Indonesia are Vietnam and Thailand. In the period, Vietnam has exported 471,605 tons of rice per year on average, while Thailand is in second place with a relatively large export of 312,458 tons of rice per year. The amount of imports shows that Indonesia is still not able to meet national rice needs.

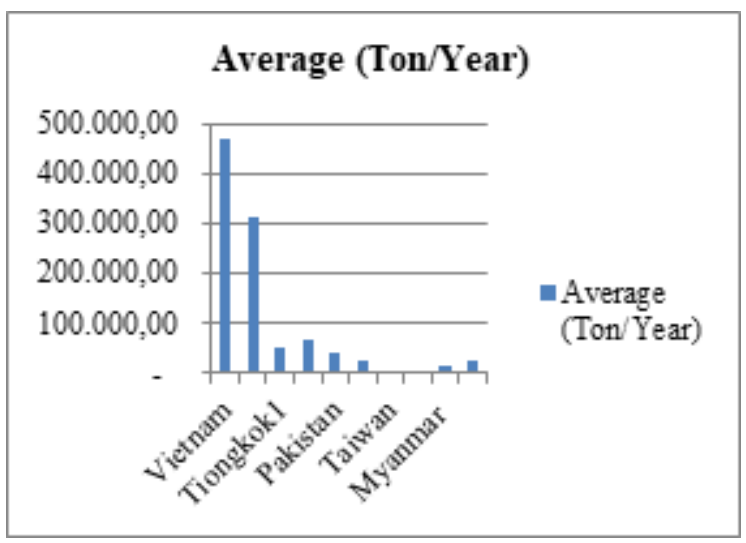

Figure 1. Average of rice imports by country of origin (tons/year)

There have been many strategies undertaken by the Indonesian government to increase rice production and productivity to achieve rice self-sufficiency, as performed in 1984. Among them is by conducting conventional or modern seed crossing techniques to obtain superior rice seeds. Advanced seed crossing techniques are carried out using a gene engineering technique called biotechnology. [2] said that gene engineering is essentially a set of technologies that are used to manipulate components genetically. The technologies can make genomic DNA or genes in one cell or creature living (organism), even from one sentient being to other living creatures that are different types [3], which has superior properties compared with the plants of their origin [4]. According to [5] that crop biotechnology develops in this last decade, which provides significant opportunities in the increase of production results and improves the quality of crop characteristics that cannot be done on a conventional cross method. The success of biotechnology is characterized by the discovery of various kinds of technologies, such as genetic engineering, tissue culture, recombinant DNA, breeding of stem cells, cloning, etc. Crop biotechnology is widely applied, especially in developed countries. [6] argued crop biotechnology is the border of the 21 st-century revolution. [7] stated that westerners often see the social components of agriculture in developing countries as constraints on development. Particular relevance to the future of genetically modified (GM) crops is the importance of the social element of indigenous management skills. Developing countries' farmers rely on observations of each other's fields, and information and interpretations passed among each other. Along with the benefits that genetic modification has the potential to offer, it is essential to keep in mind ways in which the technology may also disrupt this social component of agriculture. Two possible forms of disruption are decreased recognisability and accelerated rate of technological change.

It is clear that worldwide public opinion about biotechnology comprises a broad spectrum of attitudes and that opinions vary with the type of use of the technology. Asia also provides a mixed landscape as far as public opinion and acceptance of GE food are concerned. Levels of awareness of biotechnology were

* Corresponding author: ita_hani.faperta@unej.ac.id 
low in all the countries surveyed (China, India, Filipina, Japan, and South Korea) [7]. [8] stated that Indonesia, to date, still takes a cautious stance in accepting the biotechnology presence. It means not all communities accept the biotechnology presence of crops. [9] shows that Cirebon people have different perceptions of genetically modified crops. These differences result in attitudes towards the transgenic plants; differently, some agree, and some disagree. The community agrees to argue that genetically modified crops can produce food quickly so that there is no shortage of food while disagreeing to prioritize human health because gene transfer still leaves chemicals. The diversity of attitudes towards biotechnology in food crops is not only in Indonesia but also in some other countries. In the writings of [9] explained that Civil Community attitudes in Europe, Japan, and Canada agree on biotechnology applications to maintain health, e.g., biotechnology to drug or vaccine producers. In contrast, biotechnology applications in food production are not supported.

Several factors certainly cause a variation of opinions. [6] states that information is essential. The public should be given correct information regarding the benefits and risks of food plant biotechnology. Research showed the factors that take the reception of crop biotechnology are the optimism of technology, knowledge, and awareness of biotechnology, the vision of biotechnology issues, value orientation, trust in the interests of institutions, and background factors. These factors generate values of biotechnology. These values will create attitudes, so attitudes are an outgrowth of values. Both attitudes and values tend to implicit guides for action in that people often act by their values and attitudes [10].

This study is different from other researches since it chooses undergraduate students as public representatives. They, as agents of change, play an essential role in their attitude towards innovations such as agro-biotechnology, especially plants. This study aims to look at how the attitude of students, especially the faculty of agriculture, towards technological developments in their fields. As a comparison, students from other faculties will be surveyed. The selection because they will become adopters after engaging in the world of work either as producers or consumers.

Referring to the background, the purposes of this research are to explain: (1) undergraduate student attitudes toward crop biotechnology and (2) factors affecting their attitudes towards biotechnology.

\section{METHOD}

This survey research was deliberately conducted at the University of Jember campus in 2018 with nonproportioned stratified random sampling by a criterion of faculty (agriculture and non-agriculture [11]. The respondents were students of the University of Jember, consisting of 40 students of Faculty of Agriculture and 40 students of non-agricultural faculty. The determination of the number was done by accident. Data was obtained using interviews and results are analyzed descriptively. To answer the goal of the first assisted with frequency tabulation, while to answer the second purpose assisted by a logistic regression analysis tool with the following formula:

$\mathrm{Y}=\alpha+\chi X+\theta_{1} \mathrm{D}_{1}+\theta_{2} \mathrm{D}_{2}+\theta_{3} \mathrm{D}_{3}+\theta_{4} \mathrm{D}_{4}+\theta_{5} \mathrm{D}_{5}$

Which;

$\mathrm{Y}=$ dummy variables for the attitude of respondents to crops biotechnology, $\mathrm{Y}=1$ is agree, $\mathrm{Y}=0$ is refused

$\mathrm{X}=$ respondent's age (year)

$D_{1}=$ dummy variable for gender, $D_{1}=1$ is male, $D_{1}=0$ is female

$\mathrm{D}_{2}=$ dummy variable for knowledge of crops biotechnology, $\mathrm{D}_{2}=1$ is good, $\mathrm{D}_{2}=0$ is less good

$\mathrm{D}_{3}=$ dummy variable for information, $\mathrm{D}_{3}=1$ is more than one information source, $\mathrm{D}_{3}=0$ is one information source or never have been read/heard about food crop biotechnology

$\mathrm{D}_{4}=$ dummy variable for lifestyle, $\mathrm{D}_{4}=1$ is concerned about health, $\mathrm{D}_{4}=0$ is the opposite

$\mathrm{D}_{5}=$ dummy variables for faculty, $\mathrm{D}_{5}=1$ is the Faculty of Agriculture, $D_{5}=0$ is non-agricultural faculty

$\alpha=$ Constanta $\square$

$\boldsymbol{\gamma}, \theta_{1}, \theta_{2}, \theta_{3}, \theta_{4}, \theta_{5}=$ parameter

Hypothesis:

$\mathrm{H} 0: x=\theta_{1}=\theta_{2},=\theta_{3}=\theta_{4}=\theta_{5}=0$

H1: there is one or more $x, \theta_{1}, \theta_{2}, \theta_{3}, \theta_{4}, \theta_{5} \neq 0$

All data were analyzed at $95 \%$ confidence level.

\section{RESULT}

\subsection{Undergraduate student's attitudes toward biotechnology crops}

Most undergraduate students agreed with biotechnology crops; the number reach $61,25 \%$ (Fig. 2). This level shows a moderate level of agreement. Based on educational background shows that students of the faculty of agriculture have a higher level of approval than students from other faculties (Figure 3).

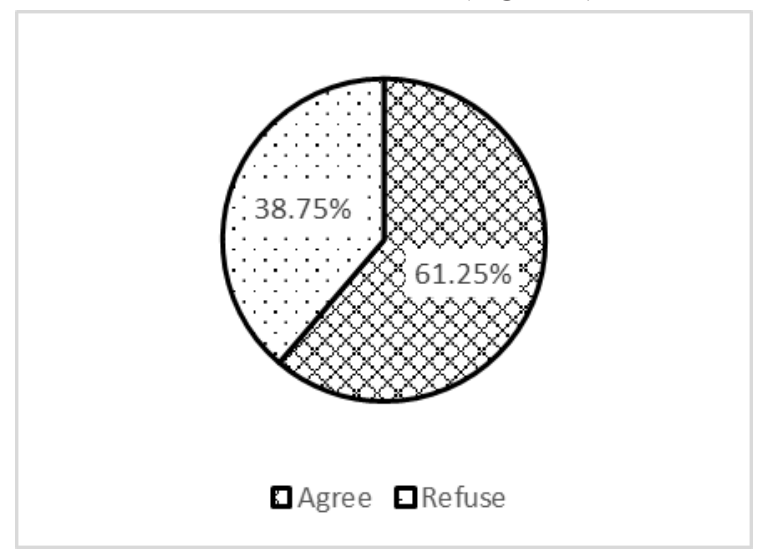

Figure 2. Agreement of respondents toward biotechnology crops 


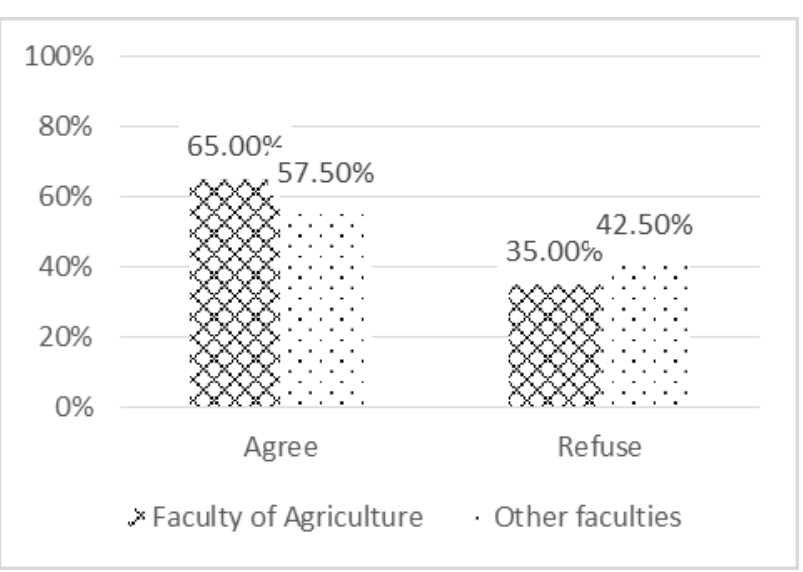

Figure 3. Agreement of respondents based on educational background

The reason for respondents who agreed with biotechnology is it will generate new superior varieties that can increase production and productivity of crops. Meanwhile, the idea of respondents who refuse crop biotechnology is it will eliminate native varieties, damage the environment, or imbalance the ecosystem and harm human health. It will also make farmers very dependent on seed companies.

\subsection{Factors affect undergraduate student's attitude toward crop biotechnology}

A logit regression model that will be used to predict the results of data analysis is tested whether it is fixed or not. Hosmer and Lemeshow test produce a significance value of 0.487 (greater than 0.05 ) at a $95 \%$ confidence level (Table 1). It means that the model can explain the data. $\square$

Table 1. Hosmer and Lemeshow test

\begin{tabular}{|c|c|c|}
\hline Chi-Square & df & Sig. \\
\hline 7,473 & 8 &, 487 \\
\hline
\end{tabular}

Another test for the model is Nagelkerke R Square. The result of 0.542 (Table 2) means that the proportion of undergraduate student's attitudes toward biotechnology crops that can be explained by the model is $54.2 \%$.

Table 2. Model Summary

\begin{tabular}{|c|c|c|}
\hline $\begin{array}{c}-\mathbf{- 2} \text { Log } \\
\text { likelihood }\end{array}$ & $\begin{array}{c}\text { Cox \& Snell R } \\
\text { Square }\end{array}$ & $\begin{array}{c}\text { Nagelkerke R } \\
\text { Square }\end{array}$ \\
\hline $66,002^{\mathrm{a}}$ &, 400 &, 542 \\
\hline
\end{tabular}

The classification table (Table 3 ) shows an overall percentage value of 85.0 . It means that the logistic regression model is quite good because it can guess correctly $85 \%$ of the conditions that occur.
Table 3. Classification table

\begin{tabular}{|c|c|c|c|}
\hline Observed & \multicolumn{2}{|c|}{ Predicated } & \multirow{2}{*}{$\begin{array}{c}\text { Percentage } \\
\text { correct }\end{array}$} \\
\hline Attitude & $\mathbf{0}$ & $\mathbf{1}$ & \\
\hline $\mathbf{0}$ & 21 & 10 & 67,7 \\
\hline $\mathbf{1}$ & 2 & 47 & 95,9 \\
\hline Overall percentage & & & 85,0 \\
\hline
\end{tabular}

Based on the results of logistic regression analysis (Table 4), the significant factors affecting undergraduate student's attitudes toward crop biotechnology are knowledge, information, and sex. Respondents whose knowledge (could explain the definition, purpose, and impact of plant biotechnology) have a source of information on more than one source, and male respondents will tend to agree toward crop biotechnology.

Table 4. Logistic regression analysis

\begin{tabular}{|c|c|c|c|}
\hline Variables & B & Sig. & Exp (B) \\
\hline Age &,- 076 &, 727 &, 927 \\
\hline Sex &,- 423 & 0,520 &, 655 \\
\hline Knowledge & 1,814 &, 009 & 6,134 \\
\hline Information & 2,565 &, 001 & 13,001 \\
\hline Lifestyle & 2,047 &, 002 & 7,743 \\
\hline Faculty &,- 420 & 0,527 &, 657 \\
\hline Constant & $-1,767$ &, 727 &, 171 \\
\hline
\end{tabular}

Based on the coefficient of regression, Exp $($ knowledge $=1,814)=6,134$ means that the tendency of someone with good knowledge will agree more than six times than someone whose knowledge is not good. The value of Exp (information $=2.565$ ) $=13,001$ indicates that someone who has more than one source of information will tend to agree more than 13 times than someone who has less than one source of information. Meanwhile, the value of Exp (lifestyle $=2,047)=7,743$ indicates that someone who has a lifestyle that pays attention to health tends to agree eight times about biotechnology crops than someone whose lifestyle does not pay attention to hygiene.

Undergraduate students with good knowledge about crop biotechnology have a favorable attitude with six times more agree than whose not. This attitude will guide their action toward crop biotechnology [10]. The students from the faculty of agriculture are more 
agreeable than from other faculty because they have studied many lectures containing biotechnology topics. This result, similar [12] to [12], surveyed high school students in Taiwan on their knowledge of and attitudes towards biotechnology. There was a positive correlation between biotechnology knowledge and attitudes toward biotechnology for current students who study Advanced Biology (AB). The attitude results showed that students today expressed less favorable opinions toward agricultural bio-technology $(\mathrm{p}<0.001)$ despite studying $\mathrm{AB}$ or not. Also, it can be done through stakeholder synchronization to spread knowledge about biotechnology [13] quickly, precisely, effectively, and efficiently.

The information factor is related to sources of information. Information is the most significant factor in providing a change in the probability of attitude toward biotechnology crops. It means that people will tend to agree on crop biotechnology if gaining complete messages of biotechnology crops from various sources. The kinds of information sources which serve biotechnology, but readers will be relieved to know that there is no novel [14]. Biotechnology as a term has only been in widespread use for about eight years, but that has been long enough for many books and periodicals using the word to appear. Abstracting journals, bibliographies, current awareness services, and databases have followed. Conferences are organized with increasing frequency, market research reports, and directories proliferate, and consultancy services thrive.

A healthy lifestyle tends to react positively toward crop biotechnology. [15] concluded that consumers responded positively to genetically modified meats when given the choice of meats produced with hormones or dyes. They have shown that lifestyle and sociodemographic variables substantially explain the support of genetically modified food (GMF). Besides, they have demonstrated that the level of resistance is context-dependent, i.e., people who resist GMF in one case may change their minds in another context (for instance, where a traditional alternative has lower benefits).

\section{CONCLUSION}

The results show that most (61.25\%) undergraduate students agree with the crop biotechnology, while others disagree as much as $38.75 \%$. They who agreed to believe with crop biotechnology some new superior varieties will be generated. In turn, it can increase the production and productivity of crops. On another side, they who refused crop biotechnology afraid it will eliminate native varieties, damage the environment, or imbalance the ecosystem and harm human health. It will also make farmers very dependent on seed companies.

Factors that have a significant effect on the attitude toward crop biotechnology are information, knowledge, and lifestyle. The information factor is related to sources of information. It means that people will tend to agree on crop biotechnology if gaining complete messages of biotechnology crops from various sources. The undergraduate students with good knowledge about crop biotechnology have a favorable attitude, and this attitude will guide their action toward crop biotechnology. The undergraduate students with a healthy lifestyle tend to react positively toward crop biotechnology.

\section{REFERENCES}

1. Badan Pusat Statistik, 2018 (2018)

2. S. G. Uzogara, 9750, (2018)

3. D. Lotter, 16, 31 (2008)

4. L. Xia, Y. Ma, Y. He, and H. D. Jones, (2011)

5. C. R. Cantor, 18, 6 (2000)

6. M. Bio, J. Biol. Trop. 14, (2014)

7. G. D. Stone, AgBioForum 7, 76 (2004)

8. Y. R. Hidayat, J. Agrijati 26, 75 (2014)

9. L. Amin, 49 (2000)

10. D. D. Umstot, Understanding Organizational Behavior (West Publishing Company, 1988)

11. A. Bryman, Social Research Methods, 4th Ed. (Oxford University Press Inc., New York, 2012)

12. S. Chen and C. Lin, 475 (2014)

13. Mustapit, S. Subekti, A. F. Sunartomo, and Rokhani, in IOP Conf. Ser. Earth Environ. Sci. (2019)

14. A. Crafts-Lighty, in Inf. Sources Biotechnol. (Palgrave, London, 1986), p. 1986

15. A. Heiman, D. R. Just, and D. Zilberman, 3, 249 (2000) 